\title{
Uji Potensi Perlekatan Bakteri Asam Laktat Isolat TLA-15 Dan TLA-20 Pada Sel Epitel Usus Tikus (Rattus norvegicus)
}

Ernanin Dyah Wijayanti dan Tri Ardyati

\author{
Jurusan Biologi Fakultas Matematika dan Ilmu Pengetahuan Alam \\ Universitas Brawijaya Malang \\ 2007
}

\begin{abstract}
ABSTRAC
In Vitro probiotic potential test that had been conducted before, which consist of probiotic bacteria test resistance toward the gastro-intestinal track $\mathrm{pH}$ and the bile salt concentration shows that the strain bacteria TLA-15 and TLA-20 had potential as probiotic bacteria. An advance test are required to fullfill the requirement as the probiotic bacteria. So that, the objective of this research are to study the viability of lactic acid bacteria strain TLA-15 and TLA-20 at the Rattus norvegicus GI track. At the first step of this research was added $4106 \mathrm{cell} / \mathrm{ml}$ lactic acid bacteria TLA-15 and TLA-20 given orally.
\end{abstract}

Key Words: Lactic Acid Bacteria, TLA-15 isolate, TLA-20 isolate, probiotik, attachment assay

\begin{abstract}
ABSTRAK
Uji potensi probiotik secara in vitro yang telah dilakukan meliputi ketahanan terhadap $\mathrm{pH}$ saluran pencernaan dan garam empedu menunjukkan bahwa isolat TLA-15 dan TLA-20 berpotensi sebagai probiotik. Uji lanjutan secara in vivo diperlukan untuk melengkapi syarat isolat tersebut sebagai probiotik. Penelitian ini bertujuan untuk mengetahui viabilitas bakteri asam laktat isolat TLA-15 dan TLA-20 di dalam saluran pencernaan dan kemampuan perlekatannya pada sel epitel usus tikus. Tahap pertama penelitian meliputi penambahan $4.10^{6} \mathrm{sel} / \mathrm{ml}$ bakteri asam laktat isolat TLA-15 dan TLA-20 pada susu skim 12,5\% yang diberikan secara oral pada tikus selama 15 hari. Hasil penelitian menunjukkan bahwa viabilitas isolat TLA-15 dalam saluran pencernaan tikus lebih tinggi dibandingkan dengan isolat TLA-20, namun hasil analisis statistik menunjukkan bahwa kedua isolat tersebut memiliki viabilitas rendah dalam saluran pencernaan tikus. Berdasarkan jumlah koloni bakteri asam laktat pada usus tikus dan kerapatan bakteri pada preparat usus tikus, dapat diketahui bahwa bakteri isolat TLA-15 dan TLA-20 mampu melekat pada usus tikus.
\end{abstract}

Kata kunci: bakteri asam laktat, isolat TLA-15, isolat TLA-20, probiotik, uji perlekatan

\section{Pendahuluan}

Bakteri asam laktat adalah bakteri yang dapat menguraikan gula dan karbohidrat lainnya serta menghasilkan sejumlah besar asam laktat sebagai produk akhir. Bakteri tersebut tidak mendegradasi atau menguraikan protein. Bakteri yang tergolong bakteri asam laktat adalah Bifidobacterium dan Lactobacillus (Mitsuoka, 1990). Bakteri asam laktat telah diketahui mampu menghambat perlekatan dan invasi patogen pada epitel intestinal secara in vitro. Penghambatan perlekatan patogen berperan dalam membantu 
mencegah atau mengurangi infeksi (Matijasic dkk., 2006). Berdasarkan penelitian Ardyati dkk. (2006), bakteri asam laktat isolat TLA-15 dan TLA-20 berpotensi sebagai probiotik. Bakteri tersebut diisolasi dari susu yang diproduksi oleh Kabupaten Tulungagung.

Probiotik mengacu pada mikroorganisme yang mampu hidup dalam saluran pencernaan dan menekan pertumbuhan bakteri patogen sehingga membantu proses pencernaan dan meningkatkan sistem imun. Uji potensi probiotik dilakukan berdasarkan toleransi terhadap garam empedu pada berbagai konsentrasi, resistensi terhadap cairan lambung (gastric juice), kemampuan reduksi kolesterol, toleransi terhadap $\mathrm{pH}$ saluran pencernaan, kemampuan bertahan hidup (viabilitas) dan kemampuan berinteraksi dengan bakteri lain dalam saluran pencernaan serta adhesi bakteri pada sel epitel usus. Bakteri asam laktat yang memenuhi kriteria seleksi probiotik memiliki beberapa persyaratan yaitu mampu memfermentasi susu baik dalam kultur tunggal maupun kultur campuran, mampu menghasilkan produk akhir fermentasi yang secara organoleptik disukai oleh konsumen, memiliki viabilitas tinggi dalam saluran pencernaan dan resisten terhadap garam empedu, $\mathrm{pH}$ saluran pencernaan dan mikroorganisme usus lainnya, terbukti aman dan bermanfaat, tidak terserap ke dalam saluran pencernaan dan tidak bersifat patogen (Jacobsen dkk., 1999).

Uji in vitro yang telah dilakukan menunjukkan bahwa isolat bakteri TLA-15 dan TLA-20 berpotensi sebagai probiotik. Hal ini ditunjukkan oleh beberapa karakter sebagai berikut: Gram positif, menggunakan laktosa sebagai sumber karbon, katalase positif, oksidase negatif, indole positif, tumbuh optimal pada kondisi aerob, toleran pada $\mathrm{pH} 3,4,5$ dan 6 serta adanya garam empedu pada konsentrasi $0,3 \%$ dan $0,5 \%$, serta mampu menghambat pertumbuhan bakteri patogen Staphylococcus aureus
(Widowati, 2005), namun belum diketahui kemampuan perlekatannya pada permukaan sel epitel usus. Salah satu karakter bakteri probiotik adalah dapat terabsorbsi pada permukaan epitel usus manusia (Lee, 2003). Penelitian ini bertujuan untuk mengetahui viabilitas isolat TLA-15 dan TLA-20 di dalam saluran pencernaan serta kemampuan perlekatan isolat tersebut pada sel epitel usus tikus.

\section{Bahan dan Metode}

Pemberian isolat bakteri pada tikus. Tikus dibagi ke dalam empat kelompok yaitu blanko, kontrol, perlakuan dengan isolat TLA-15 dan perlakuan dengan isolat TLA20. Tikus blanko tidak diberi skim milk maupun inokulum bakteri TLA-15 dan TLA-20, tikus kontrol diberi skim milk sebanyak $4 \mathrm{ml}$ tanpa penambahan inokulum, sedangkan tikus dengan perlakuan diberi 3,6 $\mathrm{ml}$ skim milk yang ditambah dengan $0,4 \mathrm{ml}$ suspensi bakteri isolat TLA-15 atau TLA20 (mengandung $4 \cdot 10^{6} \mathrm{sel} / \mathrm{ml}$ ). Pemberian suspensi isolat pada tikus dilakukan secara oral setiap hari selama 15 hari, selanjutnya tikus dibiarkan selama 7 hari kemudian dilakukan pembedahan.

Penghitungan jumlah total BAL pada feses dan usus tikus. Penghitungan total bakteri asam laktat dari feses tikus dilakukan tiga hari sekali, dimulai pada hari ke-0 atau sebelum perlakuan serta 3 dan 7 hari setelah masa perlakuan berakhir. Sedangkan penghitungan jumlah total bakteri asam laktat dari usus tikus dilakukan 7 hari setelah masa perlakuan berakhir. Jumlah koloni total BAL dihitung berdasarkan Total Plate Count (TPC) dengan metode pour plate menggunakan media MRS agar.

Pembuatan preparat usus tikus dan pengamatan. Preparat usus tikus dibuat dengan Metode Parafin (Bancroft dan Gamble, 2002), yang selanjutnya diwarnai dengan Hematoksilen-eosin (Bancroft dan Gamble, 2002) dan pewarnaan Gram menurut Benson (2002). Selanjutnya dilakukan penghitungan jumlah bakteri pada 
penamang melintang usus tikus, penghitungan jumlah dan pengukuran villi usus tikus.

\section{Hasil dan Pembahasan}

Jumlah awal bakteri asam laktat yang terdeteksi pada masing-masing feses tikus hampir sama yaitu sekitar $10^{7} \mathrm{cfu} / \mathrm{g}$ (Gambar 1A). Jumlah total bakteri asam laktat pada feses mengalami peningkatan selama masa perlakuan hingga setelah masa perlakuan berakhir. Viabilitas isolat TLA15 dan TLA-20 pada saluran pencernaan tikus dapat diketahui melalui hasil penghitungan total bakteri asam laktat pada feses karena bakteri asam laktat pada saluran pencernaan dapat terbuang melalui feses. Bakteri asam laktat yang viabel pada materi feses mengindikasikan bahwa bakteri tersebut mampu bertahan dan toleran terhadap kondisi saluran pencernaan tikus.

Isolat TLA-15 memiliki viabilitas yang lebih tinggi daripada isolat TLA-20. Hal ini ditunjukkan oleh jumlah bakteri asam laktat pada feses tikus yang diberi perlakuan isolat TLA-15 lebih tinggi daripada yang diberi perlakuan isolat TLA-20 serta perlakuan yang lainnya. Peningkatan jumlah bakteri asam laktat pada feses tikus yang diberi perlakuan isolat TLA-15 tersebut dimulai setelah perlakuan pada hari ke 9, yaitu mencapai jumlah $2,6.10^{8} \mathrm{cfu} / \mathrm{g}$, yang menunjukkan bahwa isolat tersebut sudah mampu beradaptasi pada kondisi saluran pencernaan. Penambahan bakteri isolat TLA-15 dan TLA-20 dapat mempengaruhi mikroflora yang terdapat pada saluran pencernaan. Kompetisi antara bakteri yang ditambahkan dengan mikroflora saluran pencernaan akan terjadi, baik pada awal pemberian maupun selama pemberian bakteri berlangsung.

Hasil penghitungan bakteri asam laktat pada usus tikus (Gambar 1B) menunjukkan jumlah yang tertinggi pada tikus kontrol yaitu sebesar $1,3 \cdot 10^{7} \mathrm{cfu} / \mathrm{g}$.

Jumlah bakteri asam laktat yang tinggi berdasarkan hasil penghitungan menunjukkan kandungan bakteri asam laktat yang tinggi pada permukaan usus, sedangkan jumlah bakteri asam laktat yang rendah menunjukkan adanya perlekatan bakteri pada usus. Jumlah bakteri asam laktat pada usus tikus dengan perlakuan isolat yang lebih tinggi daripada tikus kontrol dan blanko dapat diartikan bahwa tidak terjadi perlekatan bakteri, sebaliknya bila jumlah bakteri asam laktat pada usus tikus dengan perlakuan isolat lebih rendah daripada tikus kontrol dan blanko, maka terjadi perlekatan bakteri pada usus tikus.

Berdasarkan hasil penelitian dapat diketahui bahwa kedua isolat bakteri mampu melakukan perlekatan pada usus yang ditunjukkan dengan jumlah bakteri asam laktat yang rendah, sehingga dapat diartikan bahwa bakteri melekat pada usus dan tidak terlepas pada suspensi. Hal ini disebabkan karena suspensi usus yang dianalisis tidak homogen dengan larutan pengencer sehingga hasil penghitungan bakteri asam laktat yang
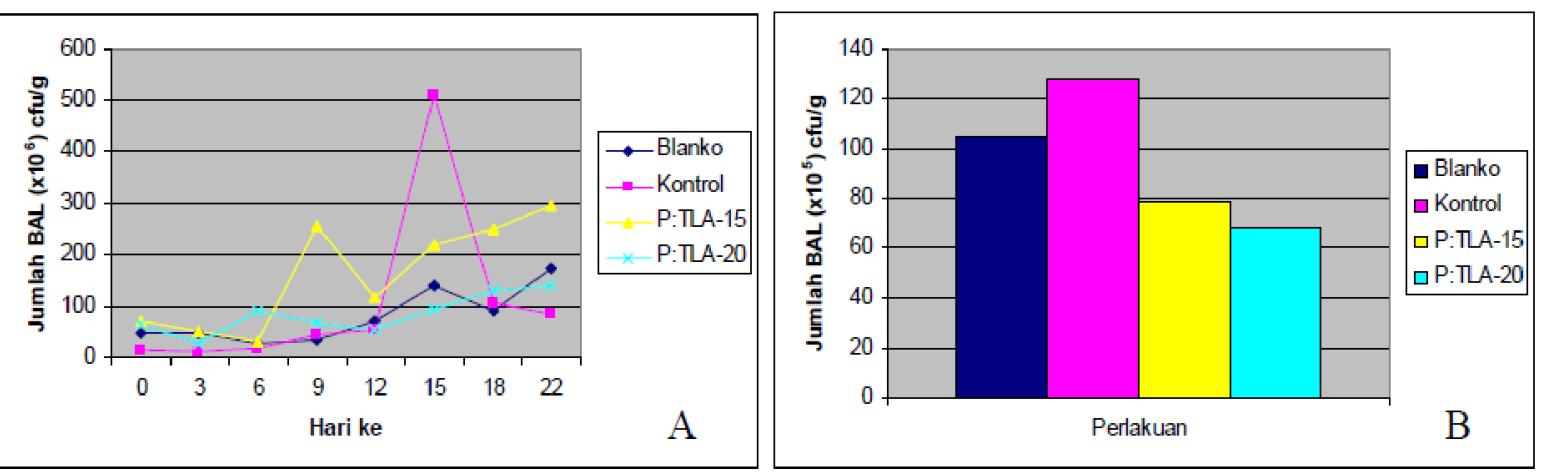

Gambar 1. Viabilitas bakteri asam laktat pada feses tikus (A) dan usus tikus (B). 


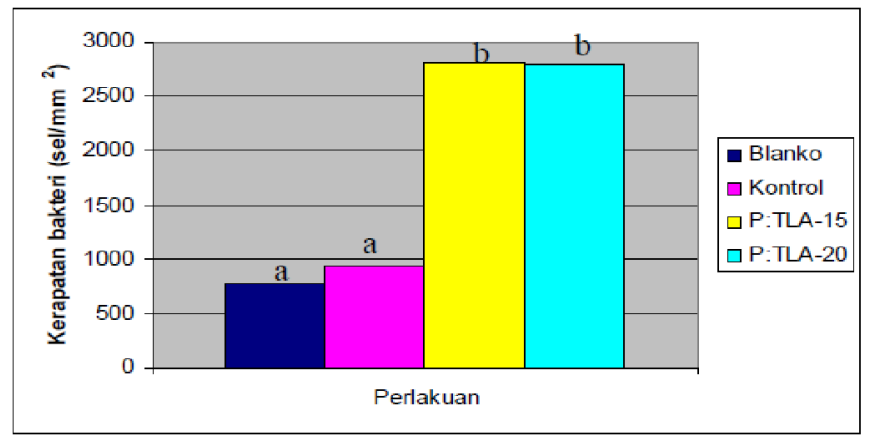

Gambar 2. Rata-rata kerapatan bakteri pada tiap luas bidang pandang preparat usus tikus. Notasi huruf yang berbeda menunjukkan nilai yang berbeda nyata.

diperoleh tidak menunjukkan jumlah bakteri yang melekat pada usus, melainkan bakteri yang terdapat pada permukaan dan tidak melekat pada usus.

Hasil uji statistik menunjukkan bahwa hasil penghitungan bakteri asam laktat dari sampel usus pada masing-masing perlakuan tidak berbeda nyata. Jumlah bakteri tidak berbeda nyata meskipun ada penambahan bakteri isolat TLA-15 dan TLA-20. Hal ini menunjukkan bahwa bakteri yang ditambahkan mampu melekat pada usus tikus. Kedua isolat bakteri mampu bertahan pada saluran pencernaan selama tujuh hari, meskipun pemberian bakteri pada tikus dihentikan. Hal ini ditunjukkan oleh hasil penghitungan bakteri asam laktat yang tinggi pada feses tikus pada hari terakhir penghitungan, serta dari hasil penghitungan bakteri pada usus tikus. Menurut Pavan dkk. (2003), bakteri asam laktat yang berpotensi sebagai probiotik mampu bertahan selama beberapa hari pada saluran pencernaan. Jumlah bakteri tersebut akan menurun dengan cepat apabila pemberian probiotik dihentikan, sehingga pemberian probiotik seharusnya diberikan secara terus-menerus. Berdasarkan hasil tersebut dapat diketahui bahwa kedua isolat bakteri berpotensi sebagai probiotik dan mampu melekat pada sel epitel usus tikus.

Hasil penghitungan jumlah bakteri pada penampang melintang usus halus tikus menunjukkan bahwa pemberian isolat, baik TLA-15 maupun TLA-20, memberikan jumlah bakteri yang tinggi masing-masing sebanyak $2809,3 \mathrm{sel} / \mathrm{mm}^{2}$ dan $2790,67 \mathrm{sel} /$ $\mathrm{mm}^{2}$. Berdasarkan hasil tersebut dapat diketahui bahwa isolat TLA-15 dan TLA20 mampu bertahan dalam usus tikus dan melekat pada sel epitel usus tikus karena jumlah bakteri asam laktat yang terdeteksi pada sampel usus juga menunjukkan adanya perlekatan bakteri pada sel epitel usus.

Menurut Gusils dkk. (2002), perlekatan bakteri pada sel epitel mukosa merupakan hasil proses pengikatan khusus antara adhesin permukaan pada bakteri dan reseptor mukosal pada membran sel. Proses perlekatan bakteri berhubungan dengan passive force, interaksi elektrostatik, hidrofobisitas, asam lipoteikoat dan struktur khusus seperti external appendages (lektin) dan polimer ekstraseluler. Golongan Lactobacillus diketahui melekat pada dinding gastrointestinal tract dengan substansi ekstraseluler yang mengandung polisakarida, protein, lipid dan asam lipoteikoat. Asam lipoteikoat tersebut berperan penting dalam perlekatan bakteri.

Perlekatan bakteri pada sel epitel usus dapat mempengaruhi villi usus. Hasil pengamatan preparat usus tikus yang telah dilakukan menunjukkan bahwa pemberian isolat pada tikus dapat mempengaruhi jumlah dan panjang villi usus tikus (Gambar 3).

Pemberian isolat TLA-15 mampu meningkatkan jumlah villi, namun tidak meningkatkan panjang villi, sedangkan pemberian isolat TLA-20 mampu meningkatkan panjang villi namun tidak meningkatkan jumlah villi. Peningkatan jumlah dan panjang villi dapat ditentukan 
melalui jumlah villi yang lebih banyak daripada blanko dan kontrol, serta ukuran villi yang lebih panjang daripada blanko dan kontrol. Hasil analisis statistik menunjukkan bahwa jumlah maupun panjang semua villi dari masing-masing tikus perlakuan tidak berbeda nyata meskipun terdapat peningkatan jumlah dan panjang villi pada tikus yang diberi perlakuan isolat. Kedua isolat bakteri diketahui mampu melekat pada usus namun belum dapat memberikan pengaruh yang signifikan pada villi tikus.

Menurut Budiño dkk. (2005), pemberian probiotik dapat meningkatkan jumlah dan panjang villi usus, dan dari beberapa penelitian sebelumnya belum ada yang menyebutkan tentang peningkatan lebar villi karena yang lebih ditekankan adalah panjang villi. Peningkatan jumlah dan panjang villi dapat memperluas daerah absorsi makanan sehingga meningkatkan efisiensi kerja usus dalam mencerna makanan. Bakteri probiotik mampu meningkatkan jumlah dan panjang villi karena adanya invasi bakteri ke dalam villi. Bakteri masuk ke dalam villi melalui brush border pada mikrovilli, dimana ukuran brush border tersebut hanya dapat dilalui oleh golongan Lactobacillus. Adanya invasi bakteri tersebut diduga mampu mempengaruhi morfologi villi menjadi memanjang dan jumlahnya meningkat. Berdasarkan hasil penelitian dapat diketahui bahwa kedua isolat bakteri yang digunakan memiliki pengaruh yang berbeda terhadap morfologi villi, meskipun tidak signifikan. Hal ini menunjukkan bahwa masing-masing bakteri probiotik memiliki aksi dan manfaat yang berbeda-beda sehingga penggunaan bakteri probiotik seharusnya tidak hanya dari satu jenis bakteri saja, tetapi berupa kultur campuran dari beberapa jenis bakteri supaya mampu memberikan pengaruh lebih optimal dan manfaat yang lebih baik.

\section{Kesimpulan}

Viabilitas bakteri asam laktat isolat TLA-15 dalam saluran pencernaan tikus lebih tinggi daripada bakteri isolat TLA-20, namun hasil analisis statistik menunjukkan bahwa kedua isolat tersebut memiliki viabilitas rendah dalam saluran pencernaan tikus. Berdasarkan jumlah koloni bakteri asam laktat pada usus tikus dan kerapatan bakteri pada preparat usus tikus, dapat diketahui bahwa bakteri isolat TLA-15 dan TLA-20 mampu melekat pada sel epitel usus tikus sehingga memenuhi kriteria sebagai probiotik.

\section{Daftar Pustaka}

Ardyati, T., Subardjo, C. Mahdi dan A. Srihardiastuti. 2006. Diversifikasi Produk Susu Melalui Teknologi Fermentasi dan Eksplorasi Probiotik di Kabupaten Tulungagung. Laporan PRSD RISTEK. Fakultas Matematika dan Ilmu Pengetahuan Alam Universitas Brawijaya. Malang

Bancroft, J. D. dan M. Gamble. 2002. Theory and Practice of Histological Techniques. Harcourt Publishers Limited. London. 796 halaman

Benson, H. J. 2002. Microbiological Applications Laboratory Manual In General Microbiology. Eightth Edition. McGraw Hill. Boston. 50 Halaman

Budiño, F. E. L., M. C. Thomaz, R. N. Kronka, L. S. O. Nakaghi, F. M. Tucci, A. L. Fraga, A. J. Scandolera, R. A. R. Huaynate. 2005. Effect of Probiotic and Prebiotic Inclusion in Weaned Piglet Diets on Structure and Ultra-structure of Small Intestine. Brazilian Archives of Biology and Technology. Vol. 48 (6) Gusils, C., S. Cuozzo, F. Sesma dan S. González. 2002. Examination of Adhesive Determinants in Three Species of Lactobacillus Isolated from Chicken. Canada Journal Microbiology. 48: (3442)

Jacobsen, C. N., V. R. Nielsen., A. E. Hayford., P. L. Moller., K. F. Michaelsen., A. Paerreagaard., B. Sandstorm., M. Tvede dan M. Jacobsen. 
1999. Screening of Probiotic Activities of Forty Seven Strain of Lactobacillus spp. by In Vitro Techniques and Evaluation of the Colonization Ability of Five Selected Strains in Human. App. and Env. Microbiology. J. 65 (11): 49494956

Lee, C. H. 2003. Creative Fermentation Technology for the Future. http:// www.worldofscience.org. Tanggal akses 10 agustus 2005

Matijasic, B. B., M. Narat, M. Z. Peternel, I. Rogelj. 2006. Ability of Lactobacillus gasseri $\mathrm{K} 7$ to Inhibit Escherichia coli Adhesion In Vitro on Caco-2 cells and Ex Vivo on Pigs' Jejunal Tissue. International Journal of Food Microbiology. 107 (92 - 96)

Mitsuoka, T. 1990. A Profile of Intestinal Bacteria. Yakult Honsha Co., Ltd. Tokyo. Hal. 21; 36-37

Pavan, S., P. Desreumax dan A. Mercenier. 2003. Use of Mouse Models To Evaluate the Persistence, Safety and Immune Modulation Capacities of Lactic Acid Bacteria. American Society for Microbiology. 10(4): 696-701

Widowati, E. 2005. Isolasi Bakteri Asam Laktat dari Susu Produksi Kabupaten Tulungagung dan Potensinya sebagai probiotik. SKRIPSI. Fakultas Matematika dan Ilmu Pengetahuan Alam Universitas Brawijaya. Malang 